\title{
The Revised Intrinsic/Extrinsic Religious Orientation Scale in a Sample of Attica's Inhabitants
}

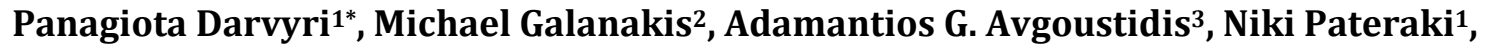 \\ Spyros Vasdekis ${ }^{4}$, Christina Darviri ${ }^{1}$ \\ ${ }^{1}$ Postgraduate Course Stress Management and Health Promotion, School of Medicine, University of Athens, \\ Athens, Greece \\ ${ }^{2}$ Panteion University of Social and Political Sciences, Athens, Greece \\ ${ }^{3}$ Pastoral Theology and Psychology, Theological School, National and Kapodistrian University of Athens, Athens, \\ Greece \\ ${ }^{4}$ Athens University Vascular Unit, University Hospital "Attikon”, Athens, Greece \\ Email: ${ }^{*}$ pandarviri@yahoo.gr
}

Received 2 June 2014; revised 1 July 2014; accepted 25 July 2014

Copyright (C) 2014 by authors and Scientific Research Publishing Inc.

This work is licensed under the Creative Commons Attribution International License (CC BY).

http://creativecommons.org/licenses/by/4.0/

(c) $\underset{\mathrm{EY}}{\mathrm{i}}$ Open Access

\section{Abstract}

The purpose of this research was to standardize the Greek version of the "Revised Intrinsic/Extrinsic Religious Orientation Scale" on a sample of Athen's inhabitants. This scale is based on the revised version by Gorsuch and MacPherson (1989) of the original scale by Ross (1967). 496 adults from various areas of Athens, Greece participated in this research. Men's percentage was $31.9 \%(\mathrm{~N}=158)$ and women's percentage was $67.5 \%(\mathrm{~N}=335)$, while the sample's average age was 31.33 years old, ranging from 18 to 69 . Factor analysis revealed three factors with eigenvalues above 1 which, in combination, accounted for $56.58 \%$ of the variance. Those three factors were "intrinsic religiousness", "extrinsic socially oriented religiousness" and "extrinsic personally oriented religiousness". Factorial structure on the Greek sample differed from the one of the original revised versions (intrinsic-extrinsic religiousness). According to the Scale's final structure, the $1^{\text {st }}$ factor's reliability was $\alpha=0.827$, the $2^{\text {nd }}$ factor's $\alpha=0.729$ and the $3^{\text {rd }}$ factor's $\alpha=0.466$. The results of the analysis demonstrate that the final form of the Scale can be used on similar studies concerning Greek population. Applications and value of the results are included in the discussion.

\section{Keywords}

Religiousness, Intrinsic, Extrinsic, Standardization, Reliability

\footnotetext{
${ }^{*}$ Corresponding author.
} 


\section{Introduction}

Matthews (1996) in his work defines religion as "an organized system of beliefs, practices and symbols, designed to enable closeness to God” while Levin and Schiller (1987) defined religiousness as “the degree of one’s involvement and personal significance attached to such a system” (Baldachino, 2003; Nonnemaker, McNeelyb, \& Blum, 2003).

The dominant measurable dimensions of religiousness, as defined by Koenig include: 1) “faith”, i.e. accepting the doctrines of the religious tradition; 2) "rituals", i.e. the religious practices by an organized or non-organized group; 3) “experience”, i.e. experiencing God's presence; 4) “religious knowledge”, i.e. the knowledge associated with the beliefs, scriptures and rituals which form a religious tradition; and 5) "community", i.e. the degree to which a religion constitutes a community for its members (Koenig, Smiley, \& Gonzales, 1988).

Religious Orientation Scale (ROS), developed by Allport \& Ross (1967), is one of the most broadly used methods in exploring the association between religious behavior and health (Allport \& Ross, 1967; Hunter \& Merill, 2013). ROS was developed on the basis of the theory that behind religious behavior there are motives, as stated by Allport (1950). He assumed that there are "immature" and "mature” religious orientations (Allport, 1963), which are notions that subsequently fell under "extrinsic" and "intrinsic" religious orientations respectively (Allport, 1959). Extrinsic religion is defined as a means of achieving some self-serving end, as a tool that promotes social support, comfort and self-esteem, whereas intrinsic religion is defined as being an ultimate end in itself, for those involved in this type of religion. These people are mainly encouraged by a promise for personal spiritual development and for a deeper, more meaningful relationship with God (Hills et al., 2004; Hunter \& Merrill, 2013).

Religious orientation has been a milestone in psychology of religion, during the last forty years, at least. Intrinsic orientation refers to a mature form of religious feeling which serves as the main motivation and drives for the individual's way of life, while extrinsic orientation refers to immature faith that enables the achievement of selfish goals (Tiliopoulos et al., 2007).

Over the last decades, there has been systematic research in the relationship between religion and health, mainly among general population (Ironson et al., 2002; Margeti \& Margeti, 2005; Peterman et al., 2002) and among special parts of the population, such as patients (Brady et al., 1999; Fehring, Miller, \& Shaw, 1997; Koenig, Pargament, \& Nielsen, 1998).

Religion can positively affect the promotion of healthy behavior (Hunter \& Merrill, 2013; Turner-Musa \& Wilsons, 2006) and diet (Hart et al., 2004). Religious beliefs and practices seem to have a positive impact on illness prevention, better post-surgery recovery and other mental and physical disorders' treatment (Matthews et al., 1998). A systematic review of 100 studies revealed that religious beliefs and practices are associated with positive emotions, such as sense of well-being, satisfaction with life and happiness (Koenig, McCullough, \& Larson, 2001). In those studies it is reported that there is a strong correlation between religiousness and limited unhealthy behavior, with high scores indicating lower probability for smoking and moderate alcohol consumption. Other studies reveal a positive relation between religiousness and lower blood pressure (Masters \& Knestel, 2011). Religiousness is a survival indicator for patients that undergo elective open-heart surgery. In addition, prayer seems to have a positive impact on hospitalized patients with coronary heart disease (Masters \& Knestel, 2011; McCullough et al., 2000; Oxman, Freeman, \& Manheimer, 1995).

Intrinsic religious oriented people tend to portray lower blood pressure reactivity to stress factors compared to extrinsic religious oriented people (Powell, Shahabi, \& Thoreson, 2003). Religious individuals, especially those who are substantially motivated show important benefits in stress management (Park, Cohen, \& Herb, 1990; Pollard \& Bates, 2004). A prospective study on Protestant college students found a significant prospective interaction between uncontrollable life stress and intrinsic religiousness in the prediction of depression. The relationship between uncontrollable stress and depression was positive for low intrinsic individuals, but negative for high intrinsic individuals (Crystal, Lawrence, \& Lisa, 1990). Several studies have demonstrated that intrinsic religious orientation is associated with better physical and mental health (Smith, Richards, \& Maglio, 2004; Masters et al., 2005; Salsman \& Carlson, 2005). Intrinsic religious orientation is a protective factor against mental illness, while extrinsic religious orientation has been classified as a risk factor in regards with mental illness (Hunter \& Merrill, 2013). In a study conducted to examine the relationship between religious orientation and mental health symptoms among students, extrinsic orientation emerged as the only significant predictor for hostility, anxiety and depression (Kuyel, Cesur, \& Ellison, 2012). Across bibliography a positive relation between intrinsic religiousness and conscientiousness is portrayed (Masters \& Knestel, 2011). Three studies suggest that affirming intrinsic religiousness reduces both death-thought accessibility following mortality salience, and the 
use of terror management defenses with regard to a secular belief system (Hathaway \& Pargament, 1990).

A study conducted on women diagnosed with breast cancer showed that patients classified as intrinsically religious were found to have significantly higher scores on spiritual well-being (SWB) than those classified as extrinsically religious. There was no difference in hope scores between intrinsically religious and extrinsically religious patients, although hope was positively correlated with SWB. Existential well-being, a component of SWB, was the primary contributor of hope (Mickley, Soeken, \& Belcher, 1992). Intrinsic religiosity and spiritual well-being are associated with hope and positive mood states in elderly people coping with cancer (Fehring, Miller, \& Shaw, 1997).

Another study investigated the relations between spiritual well-being (SWB), intrinsic religiousness (IR), and suicidal behavior in war veterans with chronic posttraumatic stress disorder. The veterans had significantly lower SWB scores and existential well-being (EWB) scores. Scores on the religious well-being (RWB) subscale and the IR scale did not differ significantly between the groups. Veterans' suicidality inversely correlated with SWB, EWB, RWB, and IR, with the correlation being stronger for the EWB subscale than for the RWB subscale. Veterans who had attempted suicide at least once in their lifetime, had significantly lower EWB scores than veterans who never attempted suicide. Low EWB scores may imply an increased risk of suicidality (Mickley, Soeken, \& Belcher, 1992).

There are a large number of tools available for the assessment and measurement of religious beliefs, practices, motivation and commitment (Sanea et al., 2008), which are broadly used in exploring the relation between religion and health (Koenig, McCullough, \& Larson, 2001). Hill and Hood report more than 125 measurement tools (Hill \& Pargament, 2008).

One of these scales is the Revised Religious Orientation or Revised Intrinsic/Extrinsic Religious Orientation Scale by Gorsuch and MacPherson (Gorsuch \& McPherson, 1989), which contains strong psychometric properties and is considered to be the best current measurement tool of religious orientation (Judd, 2009). This scale constitutes the revised version of Age-Universal I/E scale by (Gorsuch \& Venable, 1983; Gorsuch \& McPherson, 1989), which in turn is the revised version of the original Religious Orientation Scale (ROS) by (Allport \& Ross, 1967; Gorsuch \& Venable, 1983; Kirkpatrick, 1989). Donahue's review (Donahue, 1985) revealed that ROS scale had been used in more than 70 studies since the middle of 1980's, in order to assess the impact of religious orientation on mental and physical health (Donahue, 1985).

The original ROS scale was revised by Gorsuch and Venable to form an "Age Universal” scale which can be used on children, young adolescents as well as on people with a variety of educational levels (Gorsuch \& Venable, 1983). Kirkpatrick based on a factor analysis and reanalysis of 12 studies in the USA where the original scale was used, concluded in two different extrinsic dimensions: a personally oriented and a social oriented (Kirkpatrick, 1989). The first one refers to an extrinsic form of orientation with a personal direction "Ep", while the second one covers the extrinsic aspects which are socially centered "Es" (Hall \& Edwards 2002; Kirkpatrick, 1989).

Gorsuch and McPherson (1989) revised their own already revised Scale (1983) in order to encompass the new dimensions. The new 14-item I/E-R Scale (Tiliopoulos et al., 2007) added high predictive ability and accuracy to classification, because it establishes intrinsic and extrinsic scales as separate and distinctive structures for analysis (Gorsuch \& McPherson, 1989; Hunter \& Merrill, 2013). However, Gorsuch mentioned that we know very little about interaction between intrinsic and extrinsic motivation (Gorsuch, 1994). This scale has been weighted on several groups of population (Johnston, 2012). Several weightings have been conducted on students, such as the original weighting which has been conducted on a sample of 771 students from two secular and religious colleges in Southern California (Gorsuch \& McPherson, 1989; Judd, 2009).

Purpose: The purpose of this study is to weight the I/E-R questionnaire on a sample of Attica's inhabitants. Specifically, our goals include recording of observations in regards with mean and standard deviation in intrinsic and extrinsic religiousness, as well as recording of reliability levels and validity.

Previous standardization in Greece: In our research we studied the Scale's adaptation and psychometric properties on population of Attica and more specifically, on health professionals working at hospitals and students from various faculties of Universities and Technological Educational Institutes. Since this Scale has not been designed or standardized in Greece, our goal is to study its factorial structure, as shown in our sample.

\section{Method}

This paper studies the adaptation of Revised Religious Orientation or Revised Intrinsic/Extrinsic Religious 
Orientation Scale (I/E-R) by Gorsuch and MacPherson (Hill \& Hood, 1989) to the Greek Population. We chose (I/E-R) Scale because it contains strong psychometric properties and is considered to be the best current measurement tool of religious orientation (Judd, 2009), which has been a milestone in psychology of religion, during the last forty years, at least (Tiliopoulos et al., 2007). I/E-R Scale added high predictive ability and accuracy to classification, because it establishes intrinsic and extrinsic scales as separate and distinctive structures for analysis (Hunter \& Merrill, 2013). It has been standardized on several and different groups of population (Johnston, 2012), and it portrays good reliability levels. In particular, its intrinsic dimension has Cronbach's $\alpha=0.83$ and its overall extrinsic dimension Cronbach's $\alpha=0.65$. Its validity is well supported in a variety of studies, with intrinsic orientation defined as approximately a religion and as main motivation, and extrinsic as a neutral stance towards religion (Gorsuch \& McPherson, 1989; Judd, 2009; Tiliopoulos et al., 2007). In this research, mean and standard deviation for I scale (revised) was 37.2 and 5.8, while mean and standard deviation for E scale (revised) was 25.6 and 5.7 respectively. These mean values are similar to those found in a large number of other studies. The scales' range is not more restrictive than the range throughout the largest part of the research (Gorsuch \& McPherson, 1989; Judd, 2009).

\subsection{Participants}

496 adults from various areas of Attica participated in this research but only 468 completed the measurements sufficiently. Men's percentage was 31.9\% $(\mathrm{N}=158)$ and women's percentage $67.5 \%(\mathrm{~N}=335)$, while the sample's average age was 31.33 years old, ranging from 18 to 69 with a standard deviation of 9.9. $68.5 \%$ of the sample $(\mathrm{N}=340)$ were "single", $27.8 \%(\mathrm{~N}=138)$ "married", while $3.4 \%(\mathrm{~N}=17)$ were "divorced or widowed". As far as their educational level, $75.6 \%(\mathrm{~N}=375)$ of the sample were graduates from a higher education institution, $22.2 \%(\mathrm{~N}=110)$ were high school graduates and $1.4 \%(\mathrm{~N}=7)$ were primary or secondary school graduates. The majority of the participants $52.8 \%(\mathrm{~N}=262)$ were health professionals, $37.7 \%(\mathrm{~N}=182)$ were students, $1.4 \%(\mathrm{~N}=7)$ unemployed, and $5 \%(\mathrm{~N}=25)$ were non-health professionals (e.g. teachers).

\subsection{Tools}

Demographic data and health indicators: In order to complete this study, we created a demographic and general way of living and health data scale. In this scale we included data concerning gender, age, marital status, cohabitation status, children, care for individuals with disabilities, education level, place of residence, profession, satisfaction with income, meeting needs, weight, height, smoking habits, health status (medical history and selfevaluation), sleeping habits, eating habits, type of food consumed, TV habits, computer usage and stress.

Revised Intrinsic/Extrinsic Religious Orientation Scale: The new I/E-R Scale contains 14 questions (Tiliopoulos et al. 2007). These questions are answered on a 5-point Likert-type scale $(1=$ strongly disagree, $5=$ strongly agree). Their individual scores are summed up and result into two scores based on which the participants are divided into categories according to their external or internal spirituality (Gorsuch \& McPherson 1989). There are three inversely-worded questions which measure the intrinsic dimension (Tiliopoulos et al., 2007). Eight questions measure intrinsic religiousness and three questions measure each one of the extrinsic wings of religiousness (Gorsuch \& McPherson, 1989).

Scores range between 8 and 40 for the intrinsic scale and between 3 and 15 for each one of the extrinsic scales. Higher scores indicate higher levels of a specific religious orientation.

Reliability of intrinsic dimension has Cronbach's $\alpha=0.83$, extrinsic personal has Cronbach's $\alpha=0.57$, extrinsic social Cronbach's $\alpha=0.58$, and overall extrinsic dimension has Cronbach's $\alpha=0.65$. The Scale's validity is well supported in a variety of studies, with intrinsic orientation defined as approximately a religion and as main motivation, and extrinsic as a neutral stance towards religion (Gorsuch \& McPherson, 1989; Judd, 2009; Tiliopoulos et al., 2007).

Validity is reported to be up to 0.07 about intrinsic against extrinsic personal, 0.12 about intrinsic against extrinsic social, and 0.41 about the two extrinsic subscales (Gorsuch \& McPherson, 1989; Tiliopoulos et al., 2007).

Health locus of control measurement: We utilized the Health Locus of Control (HLoC) 18-item questionnaire, by Waltson B.S. and Waltson K.A. (Wallston et al., 1976). Individuals are invited to rate 18 statements according to the degree of their agreement on a Likert scale $(1=$ strongly disagree to $6=$ strongly agree). There are three 8-item subscales: The first subscale (HLC1) measures the degree to which the individual feels in control of his/her health. The second subscale (HLC2) measures the degree to which the individual believes that others 
control his/her health, and the third one (HLC3) measures the degree to which the individual believes that his/her health is a matter of chance. The questionnaire is weighted in Greek with high internal consistency Cronbach's alpha $=0.72$ (Stalikas, Triliva, \& Roussi, 2002).

Perceived stress measurement: Stress was measured on the basis of the 14-item Perceived Stress Scale (PSS) by Cohen S. (Cohen, Kamarck, \& Mermelstein 1983). The individual was invited to answer 7 positively stated and 7 negatively stated questions concerning his/her emotions and thoughts over the last month on a Likert scale ( 1 = Never to $5=$ Very often). Overall score was obtained by summing all the answers, having previously reversed the responses of positive questions. High score indicates higher level of perceived stress. The questionnaire has been standardized in Greece with high internal consistency (Cronbach's alpha $=0.79$ ) (Andreou et al., 2011).

\subsection{Procedure}

Translation: was carried out using forward/backward translation method (Medical Outcomes Trust, 1997) by two translators. One of them translated to questionnaire from English into Greek (forward) and subsequently, the other one translated it from Greek into English (backward), without being aware of the original questions. The forward translated version was compared with the original questionnaire and the Greek translation was corrected, as needed. The Greek version was pre-tested on a small sample (approximately five individuals) in order to trace unclear parts of the questions and to determine the final assessment of the translation.

Rights: of the Scale are reserved by its authors (Gorsuch \& McPherson, 1989), therefore we followed the necessary procedures.

\subsection{Statistics}

In the standardization of the questionnaire we used principal component analysis in order to check their structure. Following the production of the correlation matrix we checked the factor correlation for suitability by tracing statistical significance based on Bartlett's test. The same matrix was examined for correlations between 0.3 and 0.9 , in order to determine either very low or very high correlations which can cause problems in the process of analysis. We checked absence of undesirable co linearity using the determinant factor. Sampling adequacy was tested with Kaiser-Meyer-Olkin test. In order to assess the factors, we used eigenvalues charts and scree plots. The number of factors was determined by eigenvalues $>1$, according to the Kaiser's criterion. Orthogonal-varimax rotation was applied. In order to determine significant loading of the variables onto each factor, we specified the value of $\geq 0.3$. For the remaining correlations we utilized Pearson rho coefficient. Comparison of scores within the groups was performed with parametric tests e.g. t-test, ANOVA. The statistical significance level was set as $p<0.05$. We used statistics software package SPSS 20.1 (Chicago IL) to perform the analysis.

\section{Results}

The analysis was performed on 468 individuals and there were no missing values in their responses. Based on the correlation matrix, correlations ranged from 0.008 (I/E-R10 with I/E-R12) to 0.575 (I/E-R1 with I/E-R5). Determinant was 0.013 ( $\geq 0.00001)$ indicating absence of undesirable very high correlation of variables. Barlett's test of Sphericity turned out statistically significant $\left(\chi^{2}(91)=1996.075, p=0.00\right)$, indicating satisfactory correlation level among variables. KMO value is $0.833(>0.5)$, thus confirming sampling adequacy. Furthermore, $\mathrm{KMO}$ value for each variable was $>0.5$, indicating that the sample was adequate for each variable individually (Table 1).

The eigenvalues of three factors were $\geq 1$ and in combination accounted for $56.58 \%$ of the variable's variance. Scree plot indicated that three factors should be retained. Communalities had adequate mean value $(0.56)$, pointing towards retaining three factors. In the produced model there were residuals (values $\geq 0.05)<50 \%(49 \%$ for the three factors) (Figure 1).

Questions of factor 1 concern personal involvement with religion and we labeled this factor "Intrinsic" religiousness. Questions of factor 2 concern the individual's general social behavior in regards with religion, and therefore was labeled "Extrinsic social" religiousness. Questions of factor 3 concern the way the individual experiences religiousness and he/she perceives his/her own social behavior, therefore the factor was labeled "Extrinsic personal" religiousness. It should be noted that factor 3 had the lowest reliability, while rotation of one of the question was not justified due to the common positive loadings of the factors. 
Table 1. Results of principal component analysis of I/E-R questionnaire after orthogonal rotation.

\begin{tabular}{|c|c|c|c|c|}
\hline & & "Intrinsic" & "Extrinsic Social” & "Extrinsic Personal" \\
\hline I/E-R1 & I enjoy reading about my religion. & 0.737 & & \\
\hline I/E-R4 & $\begin{array}{l}\text { It is important to me to spend time in private thought } \\
\text { and prayer. }\end{array}$ & 0.712 & & \\
\hline I/E-R5 & I have often had a strong sense of God's presence. & 0.758 & & \\
\hline I/E-R6 & I pray mainly to gain relief and protection. & 0.707 & & \\
\hline I/E-R7 & $\begin{array}{l}\text { I try hard to live all my life according to my religious } \\
\text { beliefs. }\end{array}$ & 0.667 & & \\
\hline I/E-R9 & Prayer is for peace and happiness. & 0.692 & & \\
\hline I/E-R2 & I go to church because it helps me to make friends. & & 0.774 & \\
\hline I/E-R11 & I go to church mostly to spend time with my friends. & & 0.843 & \\
\hline I/E-R12 & My whole approach to life is based on my religion. & & 0.492 & \\
\hline I/E-R13 & $\begin{array}{l}\text { I go to church mainly because I enjoy seeing people } \\
\text { I know there. }\end{array}$ & & 0.776 & \\
\hline I/E-R3 & $\begin{array}{l}\text { It doesn't much matter what I believe so long as I am } \\
\text { good. }\end{array}$ & & & 0.495 \\
\hline I/E-R8 & $\begin{array}{l}\text { What religion offers me most is comfort in times of } \\
\text { trouble and sorrow. }\end{array}$ & & & 0.547 \\
\hline I/E-R10 & $\begin{array}{l}\text { Although I am religious, I don't let it affect my daily } \\
\text { life. }\end{array}$ & & & 0.593 \\
\hline I/E-R14 & $\begin{array}{l}\text { Although I believe in my religion, many other things } \\
\text { are more important in life. }\end{array}$ & & & 0.721 \\
\hline Eigenvalues & & 3.633 & 2.410 & 1.879 \\
\hline$\%$ of variance & & 25.948 & 17.212 & 13.421 \\
\hline Cronbach's $\alpha$ & & 0.827 & 0.729 & 0.466 \\
\hline
\end{tabular}

Analysis information: Determinant $=0.013$, Barlett's test: $\chi^{2}(91)=1996.075, p=0.00$, Kaiser-Myer-Olkin $=0.833$, residuals of $\geq 0.05=49 \%$, mean communality $=0.56$.

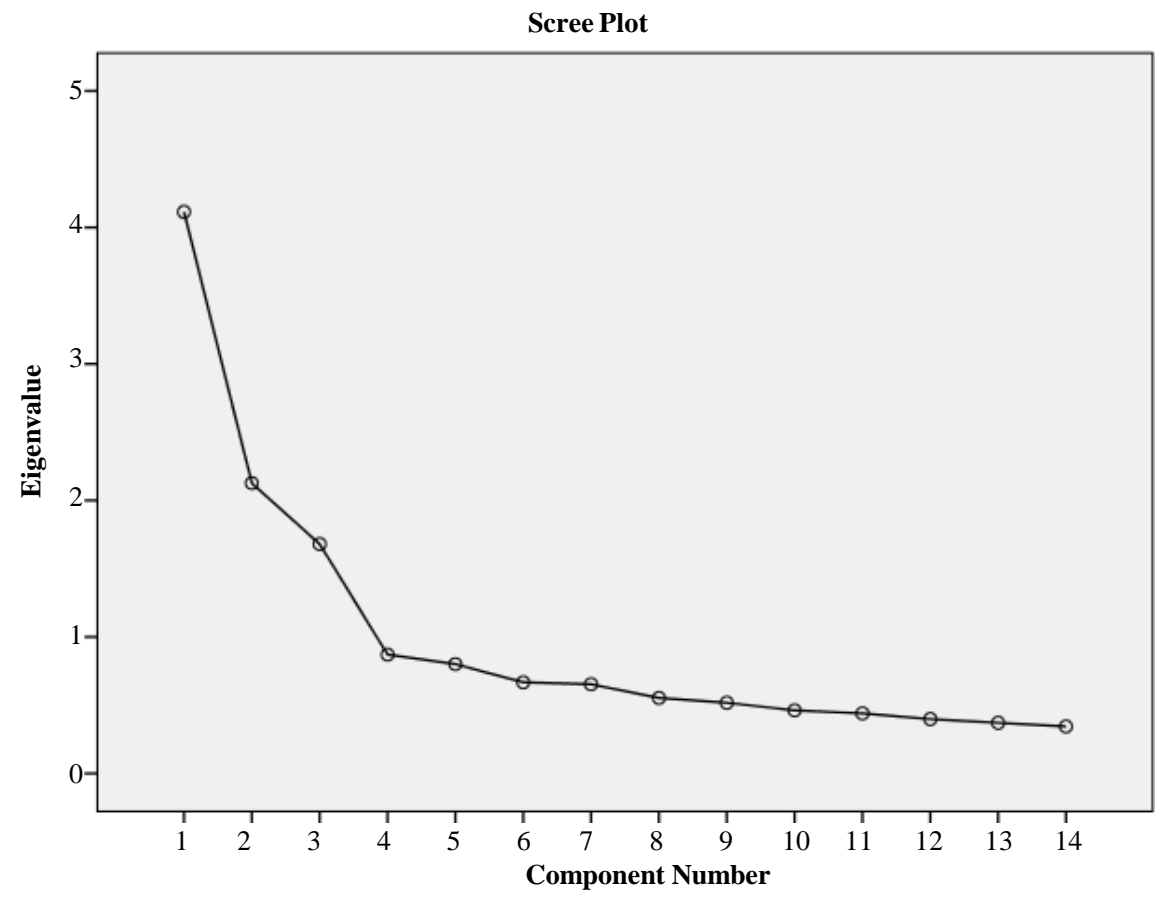

Figure 1. The scree plot of the factors' eigenvalues concerning the I/E-R questionnaire. 
Table 2 presents the subscales' basic descriptive measures (questions 1 and 5 have been reversed).

The subscales' correlation is presented on Table 3. According to this table, higher intrinsic religiousness is connected to higher extrinsic social and personal religiousness. On the contrary, extrinsic social; religiousness does not seem to relate significantly with extrinsic personal religiousness.

As presented in Table 4, there is no statistically significant difference between the scores of the questionnaire's subscales and the categories of the social-demographic factors. On the other hand, individuals with higher "intrinsic religiousness" portrayed higher internal health locus of control (Pearson's rho $=0.143^{*}, p=0.002$ ), higher external health locus of control ("powerful others"), better "Affiliation with God" (Pearson's rho = $-0.132, p=0.005$ ), higher "Satisfaction with life", and lower "Alienation from God - sense of meaningless life" (Pearson's rho $=-0.376, p<0.001$ ). Individuals with higher "extrinsic social" religiousness portrayed higher

Table 2. Descriptive measures of I/E-R questionnaire’s three subscales.

\begin{tabular}{cccccc}
\hline Factor & Number of Items & Mean & SD & Min & Max \\
\hline “Intrinsic” & 6 & 18.34 & 5.49 & 30 & 20 \\
“Extrinsic Social” & 4 & 6.18 & 2.64 & 4 & 4 \\
“Extrinsic Personal” & 4 & 13.0 & 3.24 & 20 \\
\hline
\end{tabular}

Table 3. Correlation of I/E-R scale’s factors.

\begin{tabular}{|c|c|c|c|}
\hline & “Intrinsic" & "Extrinsic Social" & “Extrinsic Personal" \\
\hline "Intrinsic" & 1 & & \\
\hline “Extrinsic Social” & $0.363^{*}$ & 1 & \\
\hline “Extrinsic Personal” & $0.138^{*}$ & -0.036 & 1 \\
\hline
\end{tabular}

${ }^{*} p<0.05$ (two-tailed).

Table 4. The social-demographic variables' impact on the three I/E-R subscales.

\begin{tabular}{|c|c|c|c|c|c|}
\hline $\begin{array}{c}\text { Social-Demographic } \\
\text { Variables }\end{array}$ & Category & $\begin{array}{l}\text { Number of } \\
\text { Participants }\end{array}$ & $\begin{array}{l}\text { "Intrinsic" } \\
\text { Mean (SD) }\end{array}$ & $\begin{array}{c}\text { “Extrinsic Social” } \\
\text { Mean (SD) }\end{array}$ & $\begin{array}{l}\text { "Extrinsic } \\
\text { Personal" } \\
\text { Mean (SD) }\end{array}$ \\
\hline \multirow{3}{*}{ Gender } & \multirow{3}{*}{$\begin{array}{c}\text { Men } \\
\text { Women }\end{array}$} & \multirow{3}{*}{$\begin{array}{l}150 \\
316\end{array}$} & $18.1(5.6)$ & $6.5(2.7)$ & $13.0(3.1)$ \\
\hline & & & $18.6(5.4)$ & $6.0(2.6)$ & $13.0(3.3)$ \\
\hline & & & $\begin{array}{c}\mathrm{t}(464)=-0.9 \\
p=0.37\end{array}$ & $\begin{array}{c}\mathrm{t}(464)=1.73 \\
p=0.08\end{array}$ & $\begin{array}{c}\mathrm{t}(464)=0.07 \\
p=0.94\end{array}$ \\
\hline \multirow{4}{*}{ Age Groups } & \multirow{4}{*}{$\begin{array}{c}<=25 \\
26-35 \\
36+\end{array}$} & \multirow{4}{*}{$\begin{array}{l}157 \\
163 \\
137\end{array}$} & $18.1(5.4)$ & $6.3(2.9)$ & $13.0(3.3)$ \\
\hline & & & $18.2(5.4)$ & $6.2(2.6)$ & $12.7(3.2)$ \\
\hline & & & $19.0(5.5)$ & $6.0(2.3)$ & 13.5 (3.3) \\
\hline & & & $\begin{array}{c}\mathrm{F}(2,454)=1.0 \\
p=0.37\end{array}$ & $\begin{array}{c}\mathrm{F}(2,454)=0.42, \\
p=0.66\end{array}$ & $\begin{array}{c}\mathrm{F}(2,454)=2.38 \\
p=0.09\end{array}$ \\
\hline \multirow{3}{*}{ Marital Status } & \multirow{3}{*}{$\begin{array}{c}\text { Married } \\
\text { Single or Divorced } \\
\text { or Widow/er }\end{array}$} & \multirow{3}{*}{$\begin{array}{l}130 \\
337\end{array}$} & $18.6(5.6)$ & $6.19(2.4)$ & $13.4(3.4)$ \\
\hline & & & $18.3(5.4)$ & $6.19(2.8)$ & $12.9(3.2)$ \\
\hline & & & $\begin{array}{c}\mathrm{t}(465)=-0.52 \\
p=0.6\end{array}$ & $\begin{array}{c}\mathrm{t}(465)=-0.02 \\
p=0.9\end{array}$ & $\begin{array}{c}\mathrm{t}(465)=-1.51 \\
p=0.13\end{array}$ \\
\hline \multirow{3}{*}{ Educational Level } & \multirow{3}{*}{$\begin{array}{c}\text { University Level } \\
\text { Primary/Secondary } \\
\text { Level }\end{array}$} & \multirow{3}{*}{$\begin{array}{l}354 \\
110\end{array}$} & $18.4(5.2)$ & $6.3(2.7)$ & 12.9 (3.3) \\
\hline & & & $18.3(5.5)$ & $6.0(2.7)$ & $13.3(3.2)$ \\
\hline & & & $\begin{array}{c}\mathrm{t}(462)=-0.15 \\
p=0.9\end{array}$ & $\begin{array}{c}\mathrm{t}(462)=-0.82 \\
p=0.4\end{array}$ & $\begin{array}{c}\mathrm{t}(462)=-1.1 \\
p=0.3\end{array}$ \\
\hline \multirow{3}{*}{ Profession } & \multirow{3}{*}{$\begin{array}{c}\text { Health } \\
\text { Professionals } \\
\text { Students }\end{array}$} & \multirow{3}{*}{$\begin{array}{l}245 \\
178\end{array}$} & $18.4(5.6)$ & $6.2(2.6)$ & $13.0(3.2)$ \\
\hline & & & $18.3(5.3)$ & $6.1(2.6)$ & 13.0 (3.3) \\
\hline & & & $\begin{array}{c}\mathrm{t}(421)=-0.18 \\
p=0.9\end{array}$ & $\begin{array}{c}\mathrm{t}(421)=-0.38 \\
p=0.7\end{array}$ & $\begin{array}{c}\mathrm{t}(421)=-0.17 \\
p=0.9\end{array}$ \\
\hline
\end{tabular}


health locus of control attributed to chance (Pearson's rho $=0.172, p<0.001$ ), higher external health locus of control ("powerful others"), and better "Affiliation with God" (Pearson's rho $=-0.132, p=0.05$ ). Individuals with higher "extrinsic personal" religiousness had higher external health locus of control ("powerful others") (Pearson's rho $=0.092, p=0.047$ ).

\section{Discussion}

Religiousness constitutes an especially significant variable in terms of health, a strong prediction and improvement factor in mental and physical health (Peacock \& Poloma, 1989). Several studies correlate it positively with the sense of well-being and positive emotions (Koenig, McCullough, \& Larson, 2001) and it also seems to contribute to self-rated welfare and positive perception of life (Frankl, 1984).

The original standardization reports the existence of two factors: the intrinsic and extrinsic religiousness. On the Greek sample this structure has only been confirmed by 50\%. In particular, we accepted intrinsic religiousness but we were obliged to accept the division of extrinsic religiousness into extrinsic personal and extrinsic social, based on the eigenvalues. These are some examples of questions concerning "extrinsic social" religiousness: "I go to church because it helps me to make friends", "I go to church mostly to spend time with my friends", "My whole approach to life is based on my religion", "I go to church mainly because I enjoy seeing people I know there". And these are some examples of questions concerning the factor of "extrinsic personal" religiousness: "It doesn't much matter what I believe so long as I am good", "What religion offers me most is comfort in times of trouble and sorrow”, “Although I am religious, I don't let it affect my daily life”, "Although I believe in my religion, many other things are more important in life".

As far as reliability is concerned, with the use of internal consistency method the scale proved to be reliable. Specifically, intrinsic religiousness subscale's reliability was $\alpha=0.827$, extrinsic social religiousness subscale's was $\alpha=0.729$, and extrinsic personal religiousness subscale's reliability was $\alpha=0.466$. Reliability of the third subscale was very low. This can be explained either due to the fewer number of questions (4) or due to the ambiguity of the subscale's first question ("It doesn't much matter what I believe so long as I am good"), on which there was double loading after the first orthogonal rotation. Alternatively, there could be one more explanation as extrinsic personal religiousness does not constitute an autonomous factor; it is in fact a sub-factor of extrinsic religiousness. However, although this explanation is plausible, was not confirmed by the questions' loadings, therefore we were not able to accept it. Future researches with different samples could potentially re-examine that possibility.

The absence of correlations with social-demographic variables is equally interesting, as it contradicts the results of previous weightings of the same questionnaire. One possible explanation could be attributed to socialcultural particularities of the Greek population, as Orthodox religion constitutes a fundamental pillar of education since young age, as well as a large number of daily practices and traditions. As a consequence, such a strong impact of Orthodox religion on the Greek sample could possibly reduce, or even eliminate the differences between the two genders, among different age groups, even among several social-economic classes, through an impact of "homogenization" of the population, at least regarding religiousness and spirituality.

The standardization procedure was conducted with some limitations. The study's entire questionnaire contained a large number of subscales which possibly placed a negative influence on part of the participants, resulting in their lack of concentration. Future researches potentially conducted on Greek population should ensure criterion and conceptual validity by distributing the questionnaire to special parts of the population with high levels of religiousness (e.g. clerics, monks, elderly people who go to church often) (convergent conceptual validity) or to special parts of the population with low levels of religiousness (e.g. young people, football funs etc.).

In the correlations conducted we found significant associations between the factors of religiousness and the health locus of control, as confirmed by the relation between spirituality and religiousness mentioned above. More particularly, individuals who felt more responsible for their own health (high internal health locus of control) portrayed greater "intrinsic religiousness", implicitly indicating high level of self-control and introspection. On the other hand, individuals that demonstrate their religiousness by expressing their beliefs through their behavior, such as through attending church services etc., had greater external health locus of control ("powerful others" and "chance”). Our overall results could be viewed as confirming the importance of self-efficacy and introspection, as expressed in health through spirituality/religiousness. 


\section{Conclusion}

In conclusion, the intrinsic/extrinsic religiousness scale can be used in a variety of researches concerning religiousness in Greece and can be associated with studies on stress, mental resilience, mental well-being, hope, optimism and general positive psychology variables or psychopathology variables. A more important point emerging from the aforementioned correlations with factor "health locus of control" is the use of this questionnaire in clinical studies in the fields of medicine and health promotion.

\section{References}

Allport, G. W. (1950). The Individual and His Religion: A Psychological Interpretation. New York, NY: Macmillan.

Allport, G. W. (1959). Religion and Prejudice. The Crane Review, 2, 1-10.

Allport, G. W. (1963). Behavioral Science, Religion, and Mental Health. Journal of Religion and Health, 2, 187-197. http://dx.doi.org/10.1007/BF01533333

Allport, G. W., \& Ross, M. J. (1967). Personal Religious Orientation and Prejudice. Journal of Personality and Social Psychology, 5, 432-443. http://dx.doi.org/10.1037/h0021212

Andreou, E., Alexopoulos, E. C., Lionis, C., Varvogli, L., Gnardellis, C., Chrousos, G. P., \& Darviri, C. (2011). Perceived Stress Scale: Reliability and Validity Study in Greece. International Journal of Environmental Research and Public Health, 8, 3287-3298. http://dx.doi.org/10.3390/ijerph8083287

Baldachino, D. (2003). Spirituality in Illness and Care. Preca Library: Malta Varitas Press.

Brady, M. J., Peterman, A. H., Fitchett, G., Mo, M., \& Cella, D. (1999). A Case for Including Spirituality in Quality of Life Measurement in Oncology. Psycho-Oncology, 8, 417-428.

http://dx.doi.org/10.1002/(SICI)1099-1611(199909/10)8:5<417::AID-PON398>3.0.CO;2-4

Cohen, S., Kamarck, T., \& Mermelstein, R. (1983). A Global Measure of Perceived Stress. Journal of Health and Social Behavior, 24, 385-396. http://dx.doi.org/10.2307/2136404

Crystal, P., Lawrence, H. C., \& Lisa, H. (1990). Intrinsic Religiousness and Religious Coping as Life Stress Moderators for Catholics versus Protestants. Journal of Personality and Social Psychology, 59, 562-574. http://dx.doi.org/10.1037/0022-3514.59.3.562

Donahue, M. J. (1985). Intrinsic and Extrinsic Religiousness: Review and Meta-Analysis. Journal of Personality and Social Psychology, 48, 400-419. http://dx.doi.org/10.1037/0022-3514.48.2.400

Fehring, R. J., Miller, J. F., \& Shaw, C. (1997). Spiritual Well-Being, Religiosity, Hope, Depression, and Other Mood States in Elderly People Coping with Cancer. Oncology Nursing Forum, 24, 663-671.

Frankl, V. (1984). Man's Search for Meaning. New York: Washington Square Press.

Gorsuch, R. L. (1994). Toward Motivational Theories of Intrinsic Religious Commitment. Journal for the Scientific Study of Religion, 33, 315-325. http://dx.doi.org/10.2307/1386491

Gorsuch, R. L., \& McPherson, S. E. (1989). Intrinsic/Extrinsic Measurement: I/E-Revised \& Single-Item Scales. Journal for the Scientific Study of Religion, 28, 348-354. http://dx.doi.org/10.2307/1386745

Gorsuch, R. L., \& Venable, G. D. (1983). Development of an Age Universal I-E Scale. Journal for the Scientific Study of Religion, 22, 181-187. http://dx.doi.org/10.2307/1385677

Hall, T. D., \& Edwards, K. J. (2002). The Spiritual Assessment Inventory: A Theistic Model and Measure for Assessing Spiritual Development. Journal for the Scientific Study of Religion, 41, 341-357. http://dx.doi.org/10.1111/1468-5906.00121

Hart, A., Tinker, L. F., Bowen, D. J., Satia-Abouta, J., \& McLarren, D. (2004). Is Religious Orientation Associated with Fat and Fruit-Vegetable Intake. Journal of the American Dietetic Association, 104, 1292-1296. http://dx.doi.org/10.1016/j.jada.2004.05.212

Hathaway, W. L., \& Pargament, K. I. (1990). Intrinsic Religiousness, Religious Coping, and Psychosocial Competence: A Covariance Structure Analysis. Journal for the Scientific Study of Religion, 29, 423-441. http://dx.doi.org/10.2307/1387310

Hill, P. C., \& Pargament, K. I. (2008). Advances in the Conceptualization and Measurement of Religion and Spirituality: Implications for Physical and Mental Health Research. Psychology of Religion and Spirituality, S, 3-17.

Hills, P., Francis, L. J., Argyle, M., \& Jackson, C. J. (2004). Primary Personality Trait Correlates of Religious Practice and Orientation. Personality and Individual Differences, 36, 61-73. http://dx.doi.org/10.1016/S0191-8869(03)00051-5

Hunter, B. D., \& Merrill, R. M. (2013). Religious Orientation and Health among Active Older Adults in the United States. Journal of Religion and Health, 52, 851-863. http://dx.doi.org/10.1007/s10943-011-9530-4 
Ironson, G., Solomon, G. F., Balbin, E. G., O’ Cleirigh, C., George, A., Kumar, M., Larson, D., \& Woods, T. E. (2002). The Ironson-Woods Spirituality/Religiousness Index Is Associated with Long Survive Health Behaviors, Less Distress, and Low Cortisol in People with HIV/AIDS. Annals of Behavioral Medicine, 24, 34-48. http://dx.doi.org/10.1207/S15324796ABM2401_05

Johnston, H. (2012). Death by Religion? Individual Differences in Attitudes about Capital Punishment. Undergraduate Honors Theses, Paper 2, Jacksonville, FL: University of North Florida. http://digitalcommons.unf.edu/honors/2

Judd, M. W. (2009). Religious Orientation, Context Effects, and Socially Desirable Responding. A Thesis, Marietta, OH: The Faculty of Marietta College.

Kirkpatrick, L. A. (1989). A Psychometrick Analysis of the Allport-Ross and Feagin Measures of Intrinsic-Extrinsic Religious Orientation. In D. O. Moberg, \& M. L. Lynn (Eds.), Research in the Social Scientific Study of Religion. Greenwich, CT: JAI Press.

Koenig, H. G., McCullough, M., \& Larson, D. B. (2001). Handbook of Religion and Health. New York: Oxford University Press. http://dx.doi.org/10.1093/acprof:oso/9780195118667.001.0001

Koenig, H. G., Pargament, K. I., \& Nielsen, J. (1998). Religious Coping and Health Status in Medically Ill Hospitalized Older Adults. Journal of Nervous and Mental Disease, 186, 513-521. http://dx.doi.org/10.1097/00005053-199809000-00001

Koenig, H. G., Smiley, M., \& Gonzales, J. A. P. (1988). Religion, Health and Aging-A Review and Theoretical Integration. Westport, CT: Greenwood Press, 172-173.

Kuyel, N., Cesur, S., \& Ellison, C. G. (2012). Religious Orientation and Mental Health: A Study with Turkish University Students. Psychological Reports, 110, 535-546. http://dx.doi.org/10.2466/02.09.PR0.110.2.535-546

Margeti, B. A., \& Margeti, B. (2005). Religiosity and Health Outcomes: Review of Literature. Collegium Antropologicum, 29, 365-371.

Masters, K. S., \& Knestel, A. (2011). Religious Motivation and Cardiovascular Reactivity among Middle Aged Adults: Is Being Pro-Religious Really that Good for You. Journal of Behavioral Medicine, 34, 449-461. http://dx.doi.org/10.1007/s10865-011-9352-6

Masters, K. S., Lensegrav-Benson, T. L., Kercher, J. C., \& Hill, R. D. (2005). Effects of Religious Orientation and Gender on Cardiovascular Reactivity among Older Adults. Research on Aging, 27, 221-240. http://dx.doi.org/10.1177/0164027504270678

Matthews, D. (1996). The Spiritual Dimensions of Medicine. In Seminar Presentation. Loma Linda, CA: Loma Linda University Medical Center.

Matthews, D. A., McCullough, M. E., Larson, D. B. et al. (1998). Religious Commitment and Health Status: A Review of the Research and Implications for Family Medicine. Archives of Family Medicine, 7, 118-124. http://dx.doi.org/10.1001/archfami.7.2.118

McCullough, M. E., Hoyt, W. T., Larson, D. B., Koenig, H. G., \& Thoreson, C. (2000). Religious Involvement and Mortality: A Meta-Analytic Review. Health Psychology, 19, 211-222. http://dx.doi.org/10.1037/0278-6133.19.3.211

Medical Outcomes Trust (1997). Trust Introduces New Translation Criteria. Trust Bulletin, 5, 1-4.

Mickley, J. R., Soeken, K., \& Belcher, A. (1992). Spiritual Well-Being, Religiousness and Hope among Women with Breast Cancer. Image-The Journal of Nursing Scholarship, 24, 267-272.

Nonnemaker, J. M., McNeelyb, C. A., \& Blum, R. W. (2003). Public and Private Domains of Religiosity and Adolescent Health Risk Behaviors: Evidence from the National Longitudinal Study of Adolescent Health. Social Science \& Medicine, 57, 2049-2054. http://dx.doi.org/10.1016/S0277-9536(03)00096-0

Oxman, T. E., Freeman Jr., D. H., \& Manheimer, E. D. (1995). Lack of Social Participation or Religious Strength and Comfort as Risk Factors for Death after Cardiac Surgery in the Elderly. Psychosomatic Medicine, 57, 5-15. http://dx.doi.org/10.1097/00006842-199501000-00002

Park, C. L., Cohen, H., \& Herb, L. (1990). Intrinsic Religiousness and Religious Coping as Life Stress Moderators for Catholics versus Protestants. Journal of Personality and Social Psychology, 59, 562-574. http://dx.doi.org/10.1037/0022-3514.59.3.562

Peacock, J. R., \& Poloma, M. M. (1989). Religiosity and Life Satisfaction across the Life Course. Social Indicators Research, 48, 319-343. http://dx.doi.org/10.1023/A:1006928028270

Peterman, A. H., Fitchett, G., Brady, M. J., Pharm, L. H., \& Cella, D. (2002). Measuring Spiritual Well-Being in People With Cancer: The Functional Assessment of Chronic Illness Therapy-Spiritual Well-Being Scale (FACIT-Sp). Annals of Behavioral Medicine, 24, 49-58. http://dx.doi.org/10.1207/S15324796ABM2401_06

Pollard, L. J., \& Bates, L. W. (2004). Religion and Perceived Stress among Undergraduates during Fall 2001 Final Examinations. Psychological Reports, 95, 999-1007. 
Powell, L. H., Shahabi, L., \& Thoreson, C. E. (2003). Religion and Spirituality: Linkages to Physical Health. The American Psychologist, 58, 36-52. http://dx.doi.org/10.1037/0003-066X.58.1.36

Salsman, J. M., \& Carlson, C. R. (2005). Religious Orientation, Mature Faith, and Psychological Distress: Elements of Positive and Negative Associations. Journal for the Scientific Study of Religion, 44, 201-209. http://dx.doi.org/10.1111/j.1468-5906.2005.00276.x

Sanea, N., Darko, M., Bjanka, V. E., Miro, J., \& Gordana, J. (2008). Spiritual Well-Being, Intrinsic Religiosity, and Suicidal Behavior in Predominantly Catholic Croatian War Veterans with Chronic Posttraumatic Stress Disorder: A Case Control Study. Journal of Nervous \& Mental Disease, 196, 79-83.

Smith, M. H., Richards, P. S., \& Maglio, C. J. (2004). Examining the Relationship between Religious Orientation and Eating Disturbances. Eating Behaviors, 5, 171-180. http://dx.doi.org/10.1016/S1471-0153(03)00064-3

Stalikas, A., Triliva, S., \& Roussi, P. (2002). The Psychometric Tools in Greece. Athens: Greek Letters. [Book in Greek]

Tiliopoulos, N., Bikker, A. P., Coxon, A. P. M., \& Hawkin, P. K. (2007). The Means and Ends of Religiosity: A Fresh Look at Gordon Allport's Religious Orientation Dimensions. Personality and Individual Differences, 42, 1609-1620. http://dx.doi.org/10.1016/j.paid.2006.10.034

Turner-Musa, J. O., \& Wilson, S. (2006). Religious Orientation and Social Support on Health-Promoting Behaviors of African-American College Students. Journal of Community Psychology, 34, 105-115. http://dx.doi.org/10.1002/jcop.20086

Wallston, B. S., Wallston, K. A., Kaplan, G. D., \& Maides, S. A. (1976). The Development and Validation of the Health Related Locus of Control (HLC) Scale. Journal of Consulting and Clinical Psychology, 44, 580-585.

http://dx.doi.org/10.1037/0022-006X.44.4.580 
Scientific Research Publishing (SCIRP) is one of the largest Open Access journal publishers. It is currently publishing more than 200 open access, online, peer-reviewed journals covering a wide range of academic disciplines. SCIRP serves the worldwide academic communities and contributes to the progress and application of science with its publication.

Other selected journals from SCIRP are listed as below. Submit your manuscript to us via either submit@scirp.org or Online Submission Portal.
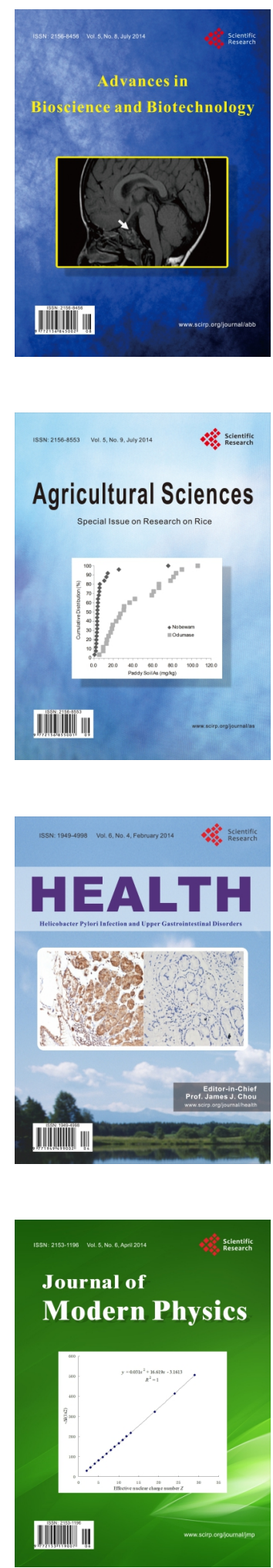
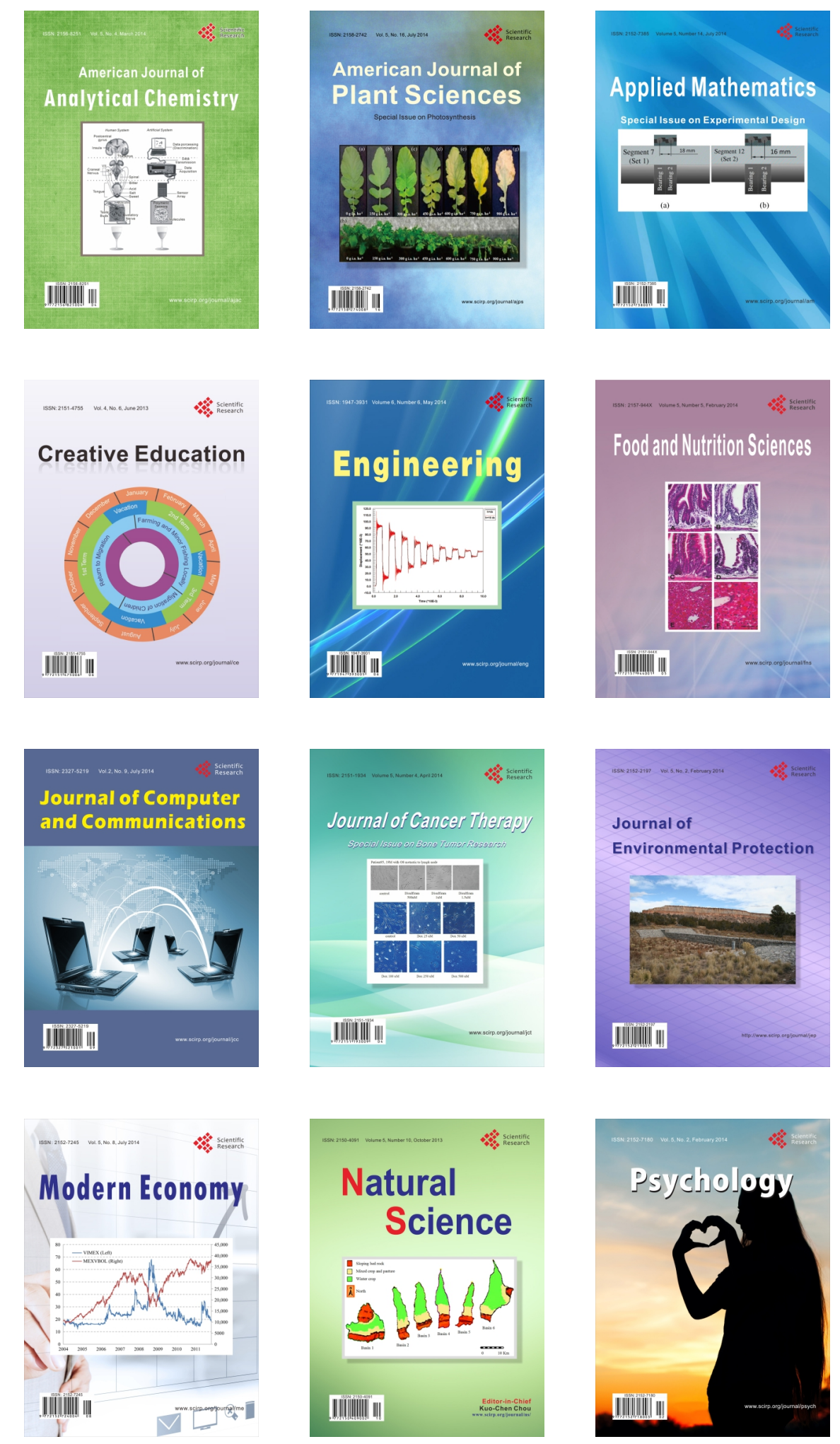